Egyptian Journal of Rabbit Science, 29 (1): 99-124(2019)

\title{
EFFECT OF USING PRICKLY PEAR AND ITS BY-PRODUCTS AS ALTERNATIVE FEED RESOURCES ON PERFORMANCE OF GROWING RABBIT.
}

Fawzia A. Hassan1*, Samia M. Mobaraz2, Mohamed M. Basyony2 ; Khalid M. Mahrose3 and Shawky A. El-Medany 4

1By-products Utilization Research Department, Animal Production Research Institute, Giza, Egypt

2 Poultry Nutrition Research Department, Animal Production Research Institute, Giza, Egypt

3 Animal and Poultry Department, Faculty of Technology and Development, Zagazig University, Zagazig, Egypt

4Regional Center for Food and Feed, Agriculture Research Center, Giza, Egypt

*Corresponding author:fawzia_amer@yahoo.com

The present study aimed to evaluate the impact of different levels of dietary replacement of barely by prickly pear fruits (PPF) and peel (PPP) on growth performance, carcass traits and antioxidant status of rabbits. A total of 75 weaned male New Zealand White (NZW) rabbits (5 weeks old) with an average initial body weight of $(596.00 \pm 13.05 \mathrm{~g})$ were randomly assigned to five experimental groups (15 rabbits for each). Five experimental diets were formulated; the first was used as a control diet (0\% PPF and PPP). The other four diets were formulated to replace barley with either PPF or PPP at the levels of 25 and $50 \%$.

Results indicated that PPF and PPP are rich sources in vitamins $C(2.4,2.8 \mu \mathrm{g} / 100 \mathrm{~g})$, vitamins $E(25,23 \mu \mathrm{g} / 100 \mathrm{~g})$ and vitamin $A(10,13 \mu \mathrm{g} / 100 \mathrm{~g})$. The content of gross energy $(G E)$ in PPF was higher than that of PPP and barley. The obtained results revealed also that average of $B W, B W G, F I$ and FCR were not affected $(P<0.05)$ by feeding growing rabbits on diet containing either PPF or PPP under each tested level (25 and 50\%) compared to rabbits group fed the control diet during (9-13) and (5-13) weeks old.

Feeding growing rabbits on diets contained $50 \%$ PPF or $50 \%$ $P P P$ resulted in noticeable improvement in both average $B W G$ and $F C R$ in comparison to the other experimental groups including the control group during the whole period (5-13 weeks old). Digestibility of $O M, C P, E E$ and $C F$ were not affected significantly by the inclusion of PPF (25 and 50\%) or PPP (25 and 50\%) compared to the control 
group. Besides, there were insignificant differences in TDN and DE among the control group and the other tested groups contained PPF or PPP under each tested level (25 or 50\%). Rabbits fed a diet containing 25 and 50\% PPP had the lowest $(P<0.05)$ NH3-N concentrations while, rabbits fed 25\% PPP supplemented diets had the highest $(P<0.05)$ TVFA value. Rabbits fed diets containing $50 \%$ $P P F$ or $50 \%$ PPP had heavier $(P<0.05)$ liver, heart and edible giblets compared the control group while, rabbits fed diet containing $50 \%$ $P P P$ showed the lowest $(P<0.05)$ abdominal fat and the higher $(P<0.05)$ values of serum antioxidant marker and enzymes (TAC, GSH-Px, SOD and CAT). Plasma triglycerides, cholesterol and LDL concentrations were decreased $(P<0.05)$ while $H D L$ concentration increased $(P<0.05)$ in $P P F$ and PPP supplemented groups compared to the control group. The inclusion of PPF or PPP in rabbit diets at a level of 25 or $50 \%$ improved economical efficiency and net revenue compared to the control group.

Conclusively, according to the circumstances of this experiment, PPF or PPP could be incorporated in growing rabbit diets up to 50\% as a partial replacement of barley, without any significant impairment of the growth performance and to achieve a better antioxidant status of rabbits and higher economic efficiency of diets.

Keywords: Prickly pear; growth performance; antioxidants; rabbits.

Cactus pear (Opuntia ficus-indica (L.) Mill.) considers an excellent natural biomass. It is a fast growing xerophtes draught resistant plant and well adapted to an arid and hot environment ( Sahoo et al. 2017). It is important to find alternatives of feedstuffs to make its use more efficient within a context of sustainable animal production. Prickly pear can be considered as an excellent and cheap source for diet supplementation (Feugang et al. 2006), as a multipurpose crop (Nazareno, 2017), and as an alternative feed (Bouzoubaâ et al. 2016, Makkar, 2017, De Oliveira et al. 2017 and Cardosoa et al., 2019), due to its efficiency in converting water to dry matter, and thus to digestible energy balanced feed (Nobel and Bobich, 2002).

Prickly pear is moderately high in sugars, starch, ether extract, crude protein, amino acids, and fiber (Bhatt and Nagar 2013; Osuna-Martinez et al. 2014; Makkar 2017), and provides vitamins and calcium that are necessary for the animal (Rodriguez-García et al., 2007). It has been reported to have great DM digestibility and also to be highly palatable in 
wild and domesticated rabbits (Zeedan et al. 2015). Prickly pear fruit has increased levels of betalains, total carotenoids, $\beta$-carotene, ascorbic acid, and is one of the best sources in total phenolic compounds (Ramadan and Mörsel, 2010 and Yahia and Mondragon-Jacobo, 2011).

The nutritional and health benefits of prickly fruit are related to its antioxidant properties due to ascorbic acid, polyphenolics, flavonoid compounds (e.g., kaempferol, quercetin, and isorhamnetin) and the mixture of yellow betaxanthin and red betacyanin pigments (Zenteno-Ramírez et al. 2018). Meanwhile, the free radical scavenging activity of the red cactus pears was related to the concentration of total phenolic compounds and ascorbic acid (Sumaya-Martínez et al. 2011).

Prickly pear has been grown for many years, especially in sandy areas, because it is extremely drought tolerant (Abdel-Nabey, 2001 and Zeedan et al., 2015). It is estimated that 58344 (tonnes/ year) in Egypt are cultivated with Opuntia in the producing area of 3996 ha. Prickly peels represent around $35-40 \%$ of the whole fruit (FAO 2014). Besides to that, Prickly pear peel could be replaced for yellow corn as a source of energy in quail diets without any adverse effect on the performance (Ragab, 2007).

Therefore, the current investigation was carried out to evaluate the effects of different levels of dietary substitution of barley by prickly pear fruits (PPF) and peel (PPP) as alternative feed resources and antioxidants on growth performance, carcass traits and antioxidant status of rabbits.

\section{MATERIALS AND METHODS}

\section{Experimental design, animals and diets}

The experiment was carried out at Borg-El Arab, Alexandria Governorate, Experimental Research Station, Animal Production Research Institute (APRI), Egypt. Prickly pear (Opuntia ficus-indica) fruits and peel were obtained from a private farm in El Kalubia Governorate, Egypt. A total of 75 weaned male New Zealand White (NZW) rabbits (5 weeks old) with an average initial body weight of $(596.00 \pm 13.05 \mathrm{~g})$ were randomly assigned to five experimental groups in a completely randomized design. Each group ( 5 replicates; 3 rabbits each) was housed in galvanized batteries $(60 \times 40 \times 24$ $\mathrm{cm})$ and provided with feeders and automatic drinkers. Feed and water were offered ad libitum. Five experimental diets were formulated; the first was used as a control diet (0\% PPF and PPP). The other four diets were formulated to replace PPF and PPP for barley at the levels of 25 and $50 \%$. As shown in Table (1), all diets were formulated to be iso-nitrogenous, 
Table (1): Feed ingredients and chemical composition of experimental diets (\%DM basis).

\begin{tabular}{|c|c|c|c|c|c|}
\hline \multirow[b]{2}{*}{$\begin{array}{c}\text { Feed Ingredients } \\
(\%)\end{array}$} & \multicolumn{5}{|c|}{ Substitution level of barley by prickly pear fruit and peel } \\
\hline & Control & $\begin{array}{l}25 \% \\
\text { PPF }\end{array}$ & $\begin{array}{l}\mathbf{5 0 \%} \\
\text { PPF }\end{array}$ & $\begin{array}{l}25 \% \\
\text { PPP }\end{array}$ & $\begin{array}{l}\mathbf{5 0 \%} \\
\text { PPP }\end{array}$ \\
\hline Soybean meal (44\%CP) & 19 & 20 & 20 & 20 & 20 \\
\hline Prickly pear & -- & 5 & 10 & 5 & 10 \\
\hline Yellow corn & 10 & 5 & 5 & 5 & 5 \\
\hline Barley & 20 & 15 & 10 & 15 & 10 \\
\hline Wheat bran & 10 & 16 & 16 & 16 & 16 \\
\hline Berseem hay & 35 & 33 & 33 & 33 & 33 \\
\hline Molasses & 3.0 & 3.0 & 3.0 & 3.0 & 3.0 \\
\hline Di- Ca- phosphate & 2.0 & 2.0 & 2.0 & 2.0 & 2.0 \\
\hline Dl-Methionine & 0.4 & 0.4 & 0.4 & 0.4 & 0.4 \\
\hline Salt & 0.3 & 0.3 & 0.3 & 0.3 & 0.3 \\
\hline Vit.-Min. premix $^{1}$ & 0.3 & 0.3 & 0.3 & 0.3 & 0.3 \\
\hline Total & 100 & 100 & 100 & 100 & 100 \\
\hline \multicolumn{6}{|c|}{ Chemical composition(\%DM basis) } \\
\hline DM & 88.38 & 88.30 & 88.49 & 88.87 & 88.24 \\
\hline $\mathrm{OM}$ & 90.27 & 90.24 & 90.21 & 90.2 & 90.19 \\
\hline $\mathrm{CP}$ & 17.30 & 17.34 & 17.41 & 17.32 & 17.43 \\
\hline $\mathrm{CF}$ & 13.93 & 14.17 & 14.45 & 14.19 & 14.47 \\
\hline $\mathrm{EE}$ & 2.20 & 2.18 & 2.19 & 2.17 & 2.20 \\
\hline NFE & 56.84 & 56.55 & 56.16 & 56.52 & 56.09 \\
\hline Ash & 9.73 & 9.76 & 9.79 & 9.80 & 9.81 \\
\hline NDF & 33.31 & 33.45 & 33.50 & 33.59 & 33.63 \\
\hline $\mathrm{ADF}$ & 18.02 & 18.10 & 18.15 & 18.23 & 18.39 \\
\hline $\mathrm{ADL}$ & 5.39 & 5.41 & 5.42 & 5.45 & 5.46 \\
\hline Hemicellulose $^{2}$ & 15.29 & 15.35 & 15.35 & 15.36 & 15.24 \\
\hline Cellulose $^{3}$ & 12.63 & 12.69 & 12.73 & 12.78 & 12.93 \\
\hline Methionine $^{4}$ & 0.64 & 0.64 & 0.64 & 0.64 & 0.64 \\
\hline Lysine $^{5}$ & 0.80 & 0.80 & 0.80 & 0.80 & 0.80 \\
\hline Calcium $^{6}$ & 1.01 & 1.01 & 1.01 & 1.01 & 1.01 \\
\hline Phosphorus ${ }^{7}$ & 0.66 & 0.66 & 0.65 & 0.65 & 0.65 \\
\hline Digestible energy $(\mathrm{Kcal} / \mathrm{Kg} \mathrm{DM})^{8}$ & 2682.1 & 2657.9 & 2658.8 & 2649.9 & 2656.6 \\
\hline \multicolumn{6}{|c|}{ 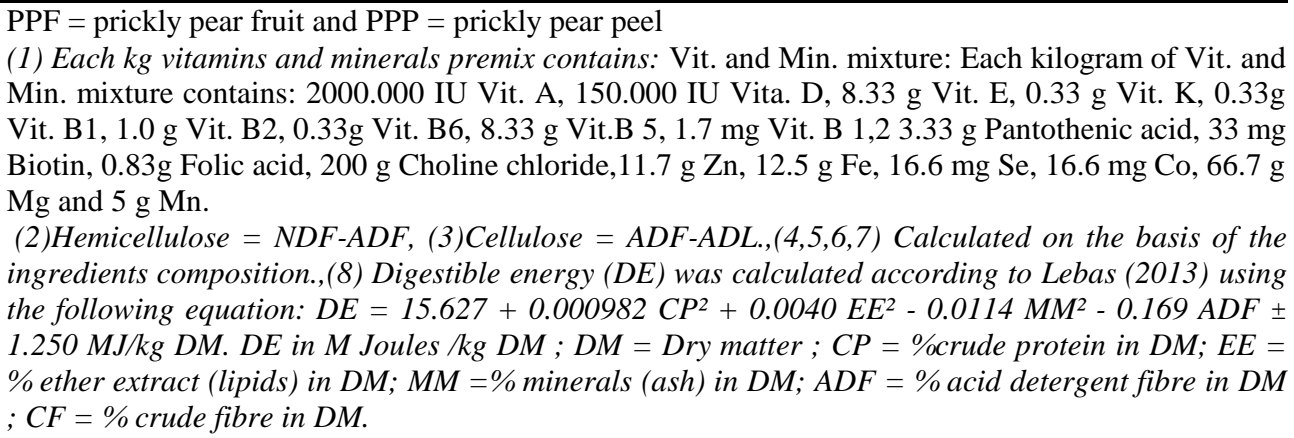 } \\
\hline
\end{tabular}


iso-caloric, and to meet all the nutrient requirements of growing rabbits according to Lebas (2013).

The experimental period lasted 8 weeks. Body weight (BW;g) and feed intake (FI; g/rabbit/period) were recorded at 5, 9 and 13 weeks of age. Body weight gain (BWG; g/rabbit/day) and feed conversion ratio (FCR; g feed/g gain) were calculated.

\section{Digestibility trials}

In vivo digestibility trials were carried out according to Perez et al. (1995). 15 male NZW rabbits were used to determine the nutrient digestibility coefficients and the nutritive value of the experimental diets (3 rabbits for each treatment). Rabbits were housed in individual metabolism cages, fed the experimental diets for a period of 1 week (adaptation period) then faeces were collected every $24 \mathrm{~h}$ for 4 consecutive days. Samples of faeces were then oven dried at $70^{\circ} \mathrm{C}$ for $48 \mathrm{~h}$, ground and stored for chemical analysis. The nutritive value of the experimental diets as DCP and TDN value were calculated according to Cheeke et al. (1982). Digestible energy (DE, $\mathrm{Kcal} / \mathrm{Kg}$ diet) was calculated as follow: $\mathrm{DE}=\mathrm{TDN} \times 44.3$ according to (Schneider and Flatt, 1975).

\section{Slaughter traits, blood constituents and antioxidant markers}

At the age of 13 weeks old, 5 rabbits from each treatment were randomly selected and fasted for $12 \mathrm{~h}$, weighed and slaughtered for carcass characteristics. Slaughter procedure and carcass analysis were carried out as described by Blasco and Ouhayoun (1996). After complete bleeding, the skin, viscera and tail were removed and the hot carcasses and its components were weighed as edible parts (liver, kidneys and heart), Dressing percentage was calculated by dividing the hot dressed carcass weight by pre-slaughter weight and expressed as a percentage according to Steven et al. (1981). Blood samples (5 ml from each rabbit) were collected during slaughter to determine blood biochemical components. Plasma was separated from blood by centrifugation at 3,000 rpm for $15 \mathrm{~min}$ and stored at $-20^{\circ} \mathrm{C}$ till assayed. Plasma total protein, albumin, triglycerides, total cholesterol, LDL and HDL-cholesterol were measured by colorimetric methods using commercial kits supplied by Bio-diagnostic, Egypt. All measurements were performed according to the manufacturer's instructions.

Total protein was determined according to Orsonneau et al. (1989). Albumin was determined according to the method of Doumas et al. (1971).

Plasma cholesterol, LDL- and HDL-cholesterol were determined according to the method of Lopez-Virella et al. (1977). Triglycerides were determined according to Wahlefeld (1974). Plasma globulin concentration 
was calculated by the difference between total protein and albumin so the Albumin/Globulin ratio was easily calculated. Superoxide dismutase (SOD), glutathione peroxidase (GSH-Px), total antioxidant capacity (TAC) and catalase (CAT) were determined by colorimetric techniques of Diamond Bio-diagnostic, Egypt. Glutathione peroxidase (GSH-Px) activity was assayed using the method of Chiu et al. (1976). Superoxide dismutase (SOD) activity was assayed according to Misra and Fridovich (1972). Total antioxidant capacity (T-AOC) was determined according to Koracevic et al. (2001), and catalase (CAT) activity was measured according to Aebi (1984).

\section{Caecum parameters}

Gastrointestinal tracts were individually removed from 5 slaughtered rabbits from each group. Cecum was weighed and $\mathrm{pH}$ of the caecal content was measured using digital $\mathrm{pH}$ meter (Orion Research Digital $\mathrm{pH}$ meter, model 201). Then, the caecal content was collected. The sample was filtered through four folds of gauze for determination of total volatile fatty acids (TVFA) by steam distillation (UDK 139- Semi-Automatic Distillation Unit) as described by Warner (1964). The N-ammonia concentration was determined by applying the Conway method (Conway, 1958).

\section{Chemical analysis}

Chemical analysis of PPF, PPP, diets and dried faeces were performed as recommended by A.O.A.C (2005) for determining moisture, crude protein $(\mathrm{CP})$, crude fiber $(\mathrm{CF})$, ether extract (EE), nitrogen free extract (NFE). Fiber fractions included neutral detergent fiber (NDF), acid detergent fiber (ADF), and acid detergent lignin (ADL) were determined sequentially according to Van Soest et al. (1991).

Gross energy (GE) of both PPF and PPP was determined by Isoperibol bomb calorimeter (Parr 1261, USA). PPF and PPP were ground by hammer mill and kept for mixing into the diet. Tannins were determined as described by Burn (1971). Saponins were determined according to Shany et al. (1970). Phytic acid was determined colorimetrically using DU 7400 spectrophotometer according to AOAC (2005). Vitamin E ( $\alpha$-tocopherol) was assayed using HPLC, according to Leth and Sondergaro (1983). Vitamin A was determined using HPLC, according to Leth and Jacobsen (1993). Vitamin C was assayed using HPLC, according to Danish official method (1996) as shown in Table 3.

\section{Economical efficiency}

To determine the economic efficiency of the experimental diets for body weight gain, the costs of feed required for producing one $\mathrm{kg}$ of body weight 
gain was calculated. The cost of the experimental diets was calculated according to the price of different ingredients prevailing at local market as well as the price of tested materials at the time of experimentation. Economical efficiency was calculated as a ratio between the return of weight gain and the cost of consumed feed.

\section{Statistical analysis}

Data were statistically analyzed by one-way ANOVA using the General Linear Model procedure of SAS (2009). Duncan's multiple range of test (Duncan, 1955) was applied to test the significant of differences between treatment means. The following model was adopted:

$$
Y_{i j}=\mu+T_{i}+E_{i j}
$$

Where: $Y_{i j}=$ an observation, $\mu=$ the overall mean; $T_{i}=$ the effect of the treatments and $\mathrm{E}_{\mathrm{ij}}=$ the experimental random error.

\section{RESULTS AND DISCUSSION}

\section{Chemical evaluation of prickly pear fruit and peel}

The chemical composition of both PPF and PPP in comparison to barley grains is illustrated in Tables 2 and 3. The results as shown in Table 2. indicated that PPF and PPP had higher CF, Ash, NDF, ADF and ADL contents and lower $\mathrm{CP}$ content compared to barley. While, the content of GE in PPF was higher than that of PPP and barley. It is worthy to notice that EE content in PPF was higher than that of barley (3.5 vs. 2.0\%). Table 3. represented a comparison between PPF and PPP concerning some vitamins content and some non-nutritional content. It could be noticed that PPF had a higher content of vitamin $\mathrm{E}$ and phytic acid content. Nevertheless, PPP contained a higher content of vitamins $\mathrm{C}$, vitamin A, phenolic compounds, tannins and saponin contents than that of PPF.

The main components of prickly pear are carbohydrate-containing polymers, which contain a mix of mucilage and pectin (Gabriel et al. 2014). About $60 \%$ of the total energy requirements of the animals could be supplied by prickly pear (López-Garcia et al. 2001). The present results are somewhat coincided with those obtained by Rodriguez-Garcia et al. (2007) and Atef et al. (2013) who reported that prickly pear pulp contained $7.61 \% \mathrm{CP}, 3.88 \%$ Ash, $85.75 \%$ Total carbohydrates, and $1.92 \%$ EE.

Guevara-Figueroa et al. (2010), Yahia and Mondragon-Jacobo (2011) and El-Mostafa et al. (2014) have already demonstrated that PPP and PPF are 
Table (2). Chemical composition of prickly Pear fruit, peel and Barley (on dry matter basis).

\begin{tabular}{lccccccccccc}
\hline $\begin{array}{c}\text { Items } \\
(\%)\end{array}$ & DM & OM & CP & CF & EE & NFE & Ash & NDF & ADF & ADL & GE* \\
\hline Barley & 92.0 & 97.30 & 9.62 & 6.30 & 2.00 & 79.38 & 2.70 & 19.01 & 8.02 & 2.04 & 3770 \\
PPF & 90.2 & 90.55 & 7.60 & 15.6 & 3.50 & 63.85 & 9.45 & 24.70 & 13.70 & 11.20 & 4289.1 \\
PPP & 84.7 & 90.39 & 7.20 & 15.1 & 1.90 & 66.19 & 9.61 & 22.10 & 13.80 & 8.90 & 3726.6 \\
\hline
\end{tabular}

*GE: Gross Energy (Kcal/Kg DM); PPF: Prickly Pear Fruit; PPP: Prickly Pear Peel. Dry matter (DM), organic matter $(\mathrm{OM})$, crude protein $(\mathrm{CP})$, ether extract $(\mathrm{EE})$, crude fiber $(\mathrm{CF})$, nitrogen free extract (NFE), neutral detergent fiber (NDF), acid detergent fiber (ADF), acid detergent lignin (ADL), and gross energy (GE).

Table (3). Vitamins content $\mathrm{C}, \mathrm{E}$ and $\mathrm{A}$ and non-nutritional compounds content of prickly pear fruit and peel (on dry matter basis)

\begin{tabular}{lcc}
\hline Components & PPF $^{*}$ & PPP $^{* *}$ \\
\hline Vitamins content & & \\
Vit C $(\mathrm{mg} / 100 \mathrm{~g})$ & 2.4 & 2.8 \\
Vit E $(\mu \mathrm{g} / 100 \mathrm{~g})$ & 25 & 23 \\
Vit A (B-carotene) $(\mu \mathrm{g} / 100 \mathrm{~g})$ & 10 & 13 \\
\hline Non-nutritional compounds content & & \\
Phenolic compounds & 11745 & 14585 \\
(ppm as gallic acid equivalent) & 0.53 & 0.35 \\
Phytic acid (g/100 g Dry matter) & 2.23 & 2.51 \\
Tannins $(\%)$ & 0.50 & 0.56 \\
Saponin $(\%)$ &
\end{tabular}

"Prickly pear fruit; ${ }^{* * *}$ Prickly pear peel.

rich in vitamins $\mathrm{A}$ and $\mathrm{E}$ and free from alkaloids that are well-known antinutritional factors. Moreover, Fernández-López et al. (2010) stated that total phenol content of prickly fruit pulp (Opuntia ficus-indica) is $218.8 \mathrm{mg} / 100 \mathrm{~g}$. Total antioxidant activities of differently colored PPF were strongly correlated with total phenolics, betalains and ascorbic acid concentrations (Yahia and Mondragon-Jacobo, 2011). Prickly pear possesses antioxidant, anti-lipidemic and antimicrobial properties (Gengatharan et al. 2015).

Prickly pear has antioxidant properties due to the existence of several compounds like vitamins $\mathrm{E}$ and $\mathrm{C}$, phenolic compounds and other nonnutritional substances (Ramadan and Mörsel, 2010 and Yahia and Mondragon-Jacobo, 2011). Phenolic compounds are effective antioxidants, since they can delay prooxidative impacts on proteins, DNA and lipids by the generation of stable radicals (Shahidi et al. 1992). Furthermore, it must be taken into consideration that higher phenolic compounds are found in the prickly pear peel, rather than the pulp (Feugang et al. 2006) and that is already found in the current work. Hence, from a nutritional point of view 
processing both fruit and pulp appears to be beneficial to the health and performance rabbits.

\section{Growth performance}

The effect of different experimental diets on growth performance of growing rabbits is shown in Table 4 . The obtained results revealed that average of BW, BWG, FI and FCR were not affected $(\mathrm{P}<0.05)$ by feeding growing rabbits on diet containing either PPF or PPP under each level (25 and 50\%) compared to group of rabbits fed the control diet during (9-13) and (5-13) weeks old. However, group of rabbits fed 50\% PPP diets consumed significantly $(\mathrm{P}<0.05)$ higher amount of feed than those groups fed the other tested diets except the control diet during (5-9 weeks old). Besides, the same group recorded higher average BWG than that group fed $25 \%$ during the same period (664.0 vs. $494.67 \mathrm{~g}$ ). The observations herein are coincided with those reported by Islam et al. (2017) and Aware et al. (2017) who concluded that dietary supplementation with prickly pear in sheep and goat has a positive effect on BWG. On the other hand, Amogne (2007) reported insignificant differences in BWG of lambs, when prickly pear replaced $0,20,40,60$ and $80 \%$ of pasture hay.

Generally, feeding growing rabbits on diets contained 50\% PPF or $50 \%$ PPP resulted in noticeable improvement in both average BWG and FCR in comparison to the other experimental groups including the control group during the whole period (5-13 weeks old). This improvement may be attributed to that prickly pear is palatable (Nefzaoui, 2017) and is characterized by high sugar (glucose and fructose) content (Feugang et al. 2006 and Bouzoubaâ et al., 2016). Prickly pear is also rich in water, minerals, vitamins and antioxidants as well as amino acids ( 8 of which are essentials) and fatty acids especially palmitic acid and Omega-6 (Feugang et al. 2006; Ramadan and Mörsel, 2010; Bhatt and Nagar, 2013; OsunaMartinez et al. 2014 and Makkar, 2017). In addition, the high water content of prickly pear serves in nutrient accumulation and transportation (AguilarYáñez et al. 2011). These nutrients could accelerate metabolism and increase energy digestibility and hence improve growth performance. Zeedan et al. (2015) attributed the improved growth performance of rabbits fed prickly pear to its mode of action that included maintenance of a beneficial microbial population and improvement of feed digestibility. The same authors added that dietary prickly pear supplementation improved feed digestibility and ammonia utilization thorough its conversion to protein. Ennouri et al.(2014) suggested that the improvement in growth performance of rabbits fed prickly pear is an effect of the activity of their 
Table (4). Growth performance of growing rabbits fed diets containing prickly pear fruits and peel during different ages.

\begin{tabular}{|c|c|c|c|c|c|c|}
\hline \multirow[b]{2}{*}{ Items } & \multicolumn{5}{|c|}{ Experimental diets } & \multirow[b]{2}{*}{ P value } \\
\hline & Control & $\begin{array}{l}25 \% \\
\text { PPF }\end{array}$ & $50 \% \mathrm{PPF}$ & $25 \%$ PPP & $\begin{array}{l}50 \% \\
\text { PPP }\end{array}$ & \\
\hline No. of Rabbits & 15 & 15 & 15 & 15 & 15 & \\
\hline $\begin{array}{l}\text { Initial body } \\
\text { weight } \\
\text { (g/rabbit) }\end{array}$ & $\begin{array}{l}608.00 \\
\pm 26.32\end{array}$ & $\begin{array}{l}576.00 \\
\pm 32.26\end{array}$ & $\begin{array}{l}608.67 \\
\pm 29.97\end{array}$ & $\begin{array}{l}581.33 \\
\pm 20.88\end{array}$ & $\begin{array}{l}606.00 \\
\pm 35.66\end{array}$ & 0.8850 \\
\hline $\begin{array}{l}\text { Final body } \\
\text { weight } \\
\text { (g/rabbit) }\end{array}$ & $\begin{array}{l}1796.00 \\
\pm 59.95\end{array}$ & $\begin{array}{l}1715.67 \\
\pm 68.60\end{array}$ & $\begin{array}{c}1811.67 \\
\pm 80.73\end{array}$ & $\begin{array}{c}1735.00 \\
\pm 53.11\end{array}$ & $\begin{array}{l}1839.33 \\
\pm 57.84\end{array}$ & 0.6326 \\
\hline \multicolumn{7}{|c|}{ Average body weight gain (g/rabbit) } \\
\hline Weeks 5-9 & $\begin{array}{c}582.00^{\text {ab }} \\
\pm 42.93\end{array}$ & $\begin{array}{c}494.67^{\mathbf{b}} \\
\pm 40.39\end{array}$ & $\begin{array}{c}542.67^{\text {ab }} \\
\pm 33.12\end{array}$ & $\begin{array}{c}545.33^{\text {ab }} \\
\pm 55.73\end{array}$ & $\begin{array}{l}664.00^{\mathrm{a}} \\
\pm 40.89\end{array}$ & 0.0497 \\
\hline Weeks 9-13 & $\begin{array}{l}606.00 \\
\pm 25.33\end{array}$ & $\begin{array}{l}645.00 \\
\pm 35.23\end{array}$ & $\begin{array}{l}660.33 \\
\pm 47.56\end{array}$ & $\begin{array}{l}608.33 \\
\pm 22.97\end{array}$ & $\begin{array}{l}569.33 \\
\pm 41.39\end{array}$ & 0.4216 \\
\hline Weeks 5-13 & $\begin{array}{c}1188.00 \\
\pm 47.03 \\
\end{array}$ & $\begin{array}{r}1139.67 \\
\pm 46.39 \\
\end{array}$ & $\begin{array}{c}1203.00 \\
\pm 59.89 \\
\end{array}$ & $\begin{array}{c}1153.67 \\
\pm 47.78 \\
\end{array}$ & $\begin{array}{c}1233.33 \\
\pm 40.93 \\
\end{array}$ & 0.6697 \\
\hline \multicolumn{7}{|c|}{ Average feed intake (g/rabbit) } \\
\hline Weeks 5-9 & $\begin{array}{c}1225.00^{\mathbf{a b}} \\
\pm 55.90\end{array}$ & $\begin{array}{c}1117.67^{\mathbf{b}} \\
\pm 58.88\end{array}$ & $\begin{array}{c}1181.47^{\mathbf{b}} \\
\pm 46.78\end{array}$ & $\begin{array}{c}1182.53^{b} \\
\pm 69.57\end{array}$ & $\begin{array}{c}1361.13^{\mathrm{a}} \\
\pm 49.56\end{array}$ & 0.0470 \\
\hline Weeks 9-13 & $\begin{array}{c}2007.33 \\
\pm 35.65\end{array}$ & $\begin{array}{c}1970.13 \\
\pm 50.23\end{array}$ & $\begin{array}{l}1953.67 \\
\pm 75.85\end{array}$ & $\begin{array}{l}1913.67 \\
\pm 53.76\end{array}$ & $\begin{array}{c}1883.00 \\
\pm 40.49\end{array}$ & 0.5110 \\
\hline Weeks 5-13 & $\begin{array}{c}3232.33 \\
\pm 65.42\end{array}$ & $\begin{array}{l}3087.8 \\
\pm 46.25\end{array}$ & $\begin{array}{c}3135.13 \\
\pm 81.76\end{array}$ & $\begin{array}{l}3096.2 \\
\pm 71.83 \\
\end{array}$ & $\begin{array}{c}3244.13 \\
\pm 68.16\end{array}$ & 0.3132 \\
\hline \multicolumn{7}{|c|}{ Feed conversion ratio (g feed/g gain) } \\
\hline Weeks 5-9 & $\begin{array}{c}2.20 \\
\pm 0.11\end{array}$ & $\begin{array}{c}2.26 \\
\pm 0.11\end{array}$ & $\begin{array}{c}2.18 \\
\pm 0.08\end{array}$ & $\begin{array}{c}2.17 \\
\pm 0.13\end{array}$ & $\begin{array}{c}2.05 \\
\pm 0.16\end{array}$ & 0.7358 \\
\hline Weeks 9-13 & $\begin{array}{c}3.31 \\
\pm 0.09\end{array}$ & $\begin{array}{c}3.05 \\
\pm 0.16\end{array}$ & $\begin{array}{c}2.96 \\
\pm 0.18\end{array}$ & $\begin{array}{c}3.15 \\
\pm 0.09\end{array}$ & $\begin{array}{c}3.31 \\
\pm 0.17\end{array}$ & 0.3414 \\
\hline Weeks 5-13 & $\begin{array}{c}2.72 \\
\pm 0.06\end{array}$ & $\begin{array}{c}2.71 \\
\pm 0.08\end{array}$ & $\begin{array}{c}2.61 \\
\pm 0.09\end{array}$ & $\begin{array}{c}2.68 \\
\pm 0.07\end{array}$ & $\begin{array}{c}2.63 \\
\pm 0.06\end{array}$ & 0.8118 \\
\hline
\end{tabular}

antioxidant, antimicrobial and anti-inflammatory compounds as well as nutrient utilization due the presence of flavonoids and phenolic acids. Moreover, prickly pear serves as a lifesaving crop for animals under hot weather conditions (Gabriel et al. 2014).

\section{Digestibility coefficients and nutritive values}

As presented in Table (5). Feeding growing rabbits on diets supplemented with PPF (25 and 50\%) or PPP (25 and 50\%) had no significant effect on digestibility coefficients of $\mathrm{OM}, \mathrm{CP}, \mathrm{EE}$ and $\mathrm{CF}$ compared to the control group. 
Table (5). Effect of dietary inclusion of prickly pear fruits and peel on digestibility coefficients and nutritive values of experimental rabbit diets.

\begin{tabular}{|c|c|c|c|c|c|c|}
\hline \multirow{2}{*}{ Items } & \multicolumn{5}{|c|}{ Experimental diets } & \multirow[b]{2}{*}{ P value } \\
\hline & Control & $\begin{array}{l}25 \% \\
\text { PPF }\end{array}$ & $\begin{array}{l}50 \% \\
\text { PPF }\end{array}$ & $\begin{array}{l}25 \% \\
\text { PPP }\end{array}$ & $\begin{array}{l}\mathbf{5 0 \%} \\
\text { PPP }\end{array}$ & \\
\hline \multicolumn{7}{|c|}{ Digestible coefficient of nutrients (\%) } \\
\hline $\mathrm{DM}$ & $\begin{array}{l}72.54^{\mathrm{a}} \\
\pm 0.03\end{array}$ & $\begin{array}{l}72.47^{\mathrm{ab}} \\
\pm 0.02\end{array}$ & $\begin{array}{l}72.40^{\mathrm{b}} \\
\pm 0.04\end{array}$ & $\begin{array}{l}72.39^{\mathrm{b}} \\
\pm 0.02\end{array}$ & $\begin{array}{l}72.37^{\mathrm{b}} \\
\pm 0.04\end{array}$ & 0.0343 \\
\hline $\mathrm{OM}$ & $\begin{array}{l}72.74 \\
\pm 0.51\end{array}$ & $\begin{array}{l}72.24 \\
\pm 0.11\end{array}$ & $\begin{array}{l}72.15 \\
\pm 0.11\end{array}$ & $\begin{array}{l}72.08 \\
\pm 0.11\end{array}$ & $\begin{array}{l}72.16 \\
\pm 0.06\end{array}$ & 0.3692 \\
\hline $\mathrm{CP}$ & $\begin{array}{l}70.27 \\
\pm 0.74\end{array}$ & $\begin{array}{l}69.49 \\
\pm 0.06\end{array}$ & $\begin{array}{l}70.11 \\
\pm 0.42\end{array}$ & $\begin{array}{l}70.42 \\
\pm 0.40\end{array}$ & $\begin{array}{l}70.38 \\
\pm 0.48\end{array}$ & 0.6446 \\
\hline $\mathrm{EE}$ & $\begin{array}{l}72.38 \\
\pm 0.32\end{array}$ & $\begin{array}{l}71.14 \\
\pm 0.94\end{array}$ & $\begin{array}{l}71.66 \\
\pm 0.92\end{array}$ & $\begin{array}{l}70.97 \\
\pm 0.85\end{array}$ & $\begin{array}{l}71.32 \\
\pm 1.47\end{array}$ & 0.8518 \\
\hline $\mathrm{CF}$ & $\begin{array}{l}44.87 \\
\pm 1.32\end{array}$ & $\begin{array}{l}47.03 \\
\pm 1.64\end{array}$ & $\begin{array}{l}46.89 \\
\pm 0.75\end{array}$ & $\begin{array}{l}47.05 \\
\pm 0.14\end{array}$ & $\begin{array}{l}45.86 \\
\pm 1.08\end{array}$ & 0.5831 \\
\hline NFE & $\begin{array}{l}77.39^{\mathrm{ab}} \\
\pm 0.84 \\
\end{array}$ & $\begin{array}{l}76.04^{\mathrm{ab}} \\
\pm 0.57 \\
\end{array}$ & $\begin{array}{l}78.38^{\mathrm{a}} \\
\pm 1.35 \\
\end{array}$ & $\begin{array}{l}74.90^{\mathrm{b}} \\
\pm 0.80 \\
\end{array}$ & $\begin{array}{l}77.79^{\mathrm{a}} \\
\pm 0.34 \\
\end{array}$ & 0.0260 \\
\hline \multicolumn{7}{|c|}{ Nutritive values } \\
\hline TDN & $\begin{array}{l}66.41 \\
\pm 0.44\end{array}$ & $\begin{array}{l}65.83 \\
\pm 0.61\end{array}$ & $\begin{array}{l}66.86 \\
\pm 0.83\end{array}$ & $\begin{array}{l}64.97 \\
\pm 0.44\end{array}$ & $\begin{array}{l}66.50 \\
\pm 0.37\end{array}$ & 0.2149 \\
\hline DCP & $\begin{array}{l}11.81^{\mathrm{a}} \\
\pm 0.12\end{array}$ & $\begin{array}{l}11.52^{b} \\
\pm 0.01\end{array}$ & $\begin{array}{l}11.55^{\mathrm{ab}} \\
\pm 0.07\end{array}$ & $\begin{array}{l}11.61^{\mathrm{ab}} \\
\pm 0.07\end{array}$ & $\begin{array}{l}11.62^{\mathrm{ab}} \\
\pm 0.08\end{array}$ & 0.0166 \\
\hline $\mathrm{DE}(\mathrm{Kcal} / \mathrm{kg})$ & $\begin{array}{l}2942.96 \\
\pm 19.28\end{array}$ & $\begin{array}{l}2916.26 \\
\pm 26.72 \\
\end{array}$ & $\begin{array}{l}2961.98 \\
\pm 36.70\end{array}$ & $\begin{array}{l}2878.17 \\
\pm 19.37\end{array}$ & $\begin{array}{l}2945.95 \\
\pm 16.26 \\
\end{array}$ & 0.2153 \\
\hline
\end{tabular}

$\mathrm{PPF}=$ prickly pear fruit and PPP $=$ prickly pear peel. Dry matter $(\mathrm{DM})$, organic matter $(\mathrm{OM})$, crude protein $(\mathrm{CP})$, ether extract (EE), crude fiber (CF), nitrogen free extract (NFE)

${ }_{\mathrm{a}, \mathrm{b}}$ Means with different superscripts in each raw differ significantly $(\mathrm{P}<0.05)$.

Conversely, the DM digestibility was decreased $(\mathrm{P}<0.05)$ with feeding growing rabbits on 50\% PPF, 25\% PPP and 50\% PPP in comparison to the control group. On the other hand, NFE digestibility was higher $(\mathrm{P}<0.05)$ with rabbit groups fed $50 \%$ PPF and 50\% PPP diets than rabbits group fed 25\% PPP diet.

Data concerning the effect of experimental diets on the nutritive values as TDN, DCP and DE revealed that rabbits group fed 25\% PPF was significantly lower in DCP than the control group. Meantime, insignificant differences were observed among 50\% PPF, $25 \%$ or $50 \%$ PPP and the control group in DCP. Besides, there were no significant differences in TDN and DE among the control group and the other groups contained PPF or PPP under each tested level (25 or 50\%). Prickly pear is highly digestible (Nefzaoui and Ben Salem, 2001; Zeedan et al. 2015). 
Results in present research revealed that increasing the level of dietary PPF or PPP up to 50\% was associated with slight decreasing in DM digestibility and noticeable increase $(\mathrm{P}<0.05)$ in NFE digestibility. In this respect, Ben Salem et al. (1996) and Zeeman (2005) found that diet DM and NFE digestibilities were improved because of the high content of easily digestible carbohydrates of prickly pear. Glucose and fructose in prickly pear were (34.0 and $30.4 \mathrm{~g} / \mathrm{kg}$ ) (Atef et al. 2013). Also, Salim et al. (2009) reported that pulp, skin and seeds of Opuntia ficus-indica contained outstanding content of soluble fiber and the adequate content and proportion of glucose to fructose. Similar results were observed by Amogne (2007) observed that DM and NFE digestibilities in lambs was significantly affected by the inclusion of prickly pear up to $80 \%$ as a replacement of pasture hay.

\section{Caecum parameters}

Regarding caecum parameters, the effect of experimental diets on cecum characteristics of growing rabbits is presented in Table 6. It could be noticed that caecum $\mathrm{pH}$ did not change due to the dietary inclusion of either PPF or PPE.

Feeding growing rabbits on diets containing PPF or PPP under each tested level except 25\% PPF recorded lower $(\mathrm{P}<0.05)$ NH3-N concentrations than the control group. On the other hand, rabbits group fed 25\% PPP supplemented diet had the highest $(\mathrm{P}<0.05)$ TVFA level, the respective values were $(6.33$ vs. $4.86,5.20,4.93$ and $4.87 \mathrm{mmol} / 100 \mathrm{ml})$ compared to the other experimental groups including the control group. Rabbit fed diets supplemented with PPF or PPP at 25 and 50\% levels resulted in an increase in total TVFA concentrations compared to the control group. These results coincided with those reported by Cordova-Torres et al., (2017) who found that the dietary inclusion of prickly pear in sheep enables greater absorption of TVFA. In addition, Misra et al. (2006) indicated that increasing prickly pear inclusion in lamb diets up to $40 \%$ led to an increase in TVFA.

The cecum $\mathrm{pH}$ values ranged from 6.29 to 6.39 . These values are lower than that reported by Belenguar et al. (2000) who showed that caecal $\mathrm{pH}$ in rabbits fed different diets based on barley or corn ranged between 6.01 and 6.17. The tendency to lower NH3-N concentrations could be attributed to greater ammonia utilization by cecal microbes. It is known that rabbits were characterized by night caecotrophy, in which were rabbits reingest the faeces and utilize the microbial protein. These observations were confirmed by Zeedan et al. (2015) who found that an increase in dietary prickly pear supplementation level up to $30 \%$ led to a decrease in NH3-N 
Table (6). Effect of dietary inclusion of prickly pear fruits and peel on caecal fermentative activities in 13-week-old rabbits

\begin{tabular}{|c|c|c|c|c|c|c|}
\hline \multirow{2}{*}{ Items } & \multicolumn{6}{|c|}{ Experimental diets } \\
\hline & Control & $\begin{array}{l}25 \% \\
\text { PPF }\end{array}$ & $\begin{array}{c}\text { 50\% P } \\
\text { PF }\end{array}$ & $\begin{array}{l}25 \% \\
\text { PPP }\end{array}$ & $\begin{array}{l}50 \% \\
\text { PPP }\end{array}$ & P value \\
\hline pH value & $\begin{array}{c}6.39 \\
\pm 0.18\end{array}$ & $\begin{array}{c}6.31 \\
\pm 0.35\end{array}$ & $\begin{array}{c}6.37 \\
\pm 0.01\end{array}$ & $\begin{array}{c}6.29 \\
\pm 0.19\end{array}$ & $\begin{array}{c}6.37 \\
\pm 0.09\end{array}$ & 0.9950 \\
\hline NH3-N (mg\100 dL) & $\begin{array}{l}33.42^{\mathrm{a}} \\
\pm 1.67\end{array}$ & $\begin{array}{c}28.82^{\text {ab }} \\
\pm 0.92\end{array}$ & $\begin{array}{l}27.45^{\mathbf{b}} \\
\pm 0.83\end{array}$ & $\begin{array}{c}24.50 \\
b^{\mathbf{c}} \\
+260\end{array}$ & $\begin{array}{l}21.10^{\mathrm{c}} \\
\pm 0.74\end{array}$ & 0.0023 \\
\hline $\begin{array}{l}\text { TVFA }(\mathbf{m m o l} / 100 \\
\text { ml)* }\end{array}$ & $\begin{array}{l}4.86^{\mathbf{b}} \\
\pm 0.44\end{array}$ & $\begin{array}{l}5.20^{\mathbf{b}} \\
\pm 0.33\end{array}$ & $\begin{array}{l}4.93^{\mathbf{b}} \\
\pm 0.83\end{array}$ & $\begin{array}{l}6.33^{\mathrm{a}} \\
\pm 0.33\end{array}$ & $\begin{array}{l}4.87^{\mathbf{b}} \\
\pm 0.40\end{array}$ & 0.015 \\
\hline
\end{tabular}

levels. Carabaño et al. (2009) reported that increased availability of a fermentable substrate could promote microbial protein synthesis, thus reducing the ammoniacal nitrogen level in the caecum. In the present study, the concentration of NH3-N in the caecal content was not linearly affected by dietary PPF and PPP.

It has been known that VFA levels in rabbit caecum depend on the age of animals, the time after feeding and dietary composition (Piattoni et al. 1995), Due to the fact that the fibrous portion of prickly pear is highly digestible, TVFA level is increased (Lebas et al. 1986). Caecum fermentation produces TVFA, which are responsible for 30 to $40 \%$ of the rabbits energy requirement for maintenance (Marty and Vernay, 1984). Volatile fatty acids also aid in the control of pathogenic organisms by helping to maintain the normal $\mathrm{pH}(6-7)$ in the caecum (Prohászka and Szemerédi, 1984; Fortun-Lamothe and Boullier, 2007).

\section{Carcass characteristics}

Carcass characteristics of rabbits as affected by PPF and PPP inclusion are presented in Table (7). The obtained results indicated that rabbits fed diets containing 50\% PPF or 50\% PPP had heavier $(\mathrm{P}<0.05)$ liver, heart and edible giblets (as \% of pre-slaughter weight) compared to the control group. Results also revealed that rabbits groups fed diet containing 25 or $50 \%$ PPP had lower $(P<0.05)$ abdominal fat percentage than the other tested experimental groups including the control group. The other carcass characteristics, except kidneys \% were not significantly influenced by the dietary levels of PPF and PPP. 
Table (7). Effect of dietary inclusion of prickly pear fruits and peel on carcass characteristics of growing rabbits at 13 weeks of age.

\begin{tabular}{|c|c|c|c|c|c|c|}
\hline \multirow[b]{2}{*}{ Items } & \multicolumn{5}{|c|}{ Experimental diets } & \multirow{2}{*}{$\begin{array}{c}P \\
\text { value }\end{array}$} \\
\hline & Control & $\begin{array}{l}25 \% \\
\text { PPF }\end{array}$ & $\begin{array}{c}50 \% \\
\text { PPF }\end{array}$ & $\begin{array}{l}25 \% \\
\text { PPP }\end{array}$ & $\begin{array}{l}50 \% \\
\text { PPP }\end{array}$ & \\
\hline $\begin{array}{l}\text { Pre-slaughter } \\
\text { weight }(\mathrm{g})\end{array}$ & $\begin{array}{l}2066.00 \\
\pm 199.76\end{array}$ & $\begin{array}{l}1802.00 \\
\pm 145.41\end{array}$ & $\begin{array}{l}2062.00 \\
\pm 91.45\end{array}$ & $\begin{array}{l}1870.00 \\
\pm 117.30\end{array}$ & $\begin{array}{l}2084.00 \\
\pm 107.17\end{array}$ & 0.4788 \\
\hline $\begin{array}{l}\text { Hot carcass } \\
\text { weight }(\mathrm{g})\end{array}$ & $\begin{array}{l}1361.00 \\
\pm 117.54\end{array}$ & $\begin{array}{l}1162.00 \\
\pm 83.03\end{array}$ & $\begin{array}{l}1317.00 \\
\pm 70.67\end{array}$ & $\begin{array}{l}1234.00 \\
\pm 89.04\end{array}$ & $\begin{array}{l}1384.00 \\
\pm 83.84\end{array}$ & 0.4072 \\
\hline $\begin{array}{c}\text { Dressing weight } \\
(\%)\end{array}$ & $\begin{array}{l}65.88 \\
\pm 0.70\end{array}$ & $\begin{array}{l}64.48 \\
\pm 0.86\end{array}$ & $\begin{array}{l}63.87 \\
\pm 1.12\end{array}$ & $\begin{array}{l}65.99 \\
\pm 0.84\end{array}$ & $\begin{array}{l}66.41 \\
\pm 1.24\end{array}$ & 0.3261 \\
\hline $\begin{array}{c}\text { Liver weight } \\
(\%)\end{array}$ & $\begin{array}{l}2.58^{\mathbf{b}} \\
\pm 0.05\end{array}$ & $\begin{array}{l}2.89^{\mathbf{a b}} \\
\pm 0.20\end{array}$ & $\begin{array}{l}3.16^{\mathrm{a}} \\
\pm 0.19\end{array}$ & $\begin{array}{l}2.76^{\mathbf{a b}} \\
\pm 0.14\end{array}$ & $\begin{array}{l}3.23^{\mathrm{a}} \\
\pm 0.16\end{array}$ & 0.0442 \\
\hline $\begin{array}{c}\text { Heart weight } \\
(\%)\end{array}$ & $\begin{array}{l}0.34^{\mathrm{c}} \\
\pm 0.02\end{array}$ & $\begin{array}{l}0.37^{\mathbf{b c}} \\
\pm 0.01\end{array}$ & $\begin{array}{l}0.44^{\mathrm{a}} \\
\pm 0.01\end{array}$ & $\begin{array}{l}0.40^{\mathbf{a b}} \\
\pm 0.02\end{array}$ & $\begin{array}{l}0.42^{\mathrm{a}} \\
\pm 0.01\end{array}$ & 0.0017 \\
\hline $\begin{array}{c}\text { Kidney weight } \\
(\%)\end{array}$ & $\begin{array}{l}0.59^{\mathbf{b}} \\
\pm 0.01\end{array}$ & $\begin{array}{l}0.64^{\mathbf{a b}} \\
\pm 0.01\end{array}$ & $\begin{array}{l}0.65^{\mathbf{a b}} \\
\pm 0.01\end{array}$ & $\begin{array}{l}0.62^{\text {bc }} \\
\pm 0.02\end{array}$ & $\begin{array}{l}0.67^{\mathrm{a}} \\
\pm 0.02\end{array}$ & 0.0051 \\
\hline $\begin{array}{l}\text { Abdominal fat } \\
(\%)\end{array}$ & $\begin{array}{l}1.38^{\mathrm{a}} \\
\pm 0.10\end{array}$ & $\begin{array}{l}1.39^{\mathrm{a}} \\
\pm 0.10\end{array}$ & $\begin{array}{l}1.16^{\mathbf{a}} \\
\pm 0.07\end{array}$ & $\begin{array}{l}0.83^{\mathbf{b}} \\
\pm 0.04\end{array}$ & $\begin{array}{l}0.64^{\mathbf{b}} \\
\pm 0.05\end{array}$ & 0.0001 \\
\hline $\begin{array}{l}\text { Edible giblets } \\
(\%)\end{array}$ & $\begin{array}{l}3.51^{\mathrm{c}} \\
\pm 0.04\end{array}$ & $\begin{array}{l}3.90^{\text {abc }} \\
\pm 0.20\end{array}$ & $\begin{array}{l}4.24^{\mathbf{a b}} \\
\pm 0.21\end{array}$ & $\begin{array}{l}3.77^{\mathbf{b c}} \\
\pm 0.13\end{array}$ & $\begin{array}{l}4.32^{\mathrm{a}} \\
\pm 0.17\end{array}$ & 0.0107 \\
\hline $\begin{array}{c}\text { Total edible parts } \\
(\%)\end{array}$ & $\begin{array}{l}69.63 \\
\pm 0.67\end{array}$ & $\begin{array}{l}68.55 \\
\pm 0.98\end{array}$ & $\begin{array}{l}68.03 \\
\pm 1.27\end{array}$ & $\begin{array}{l}69.62 \\
\pm 0.91\end{array}$ & $\begin{array}{l}70.63 \\
\pm 1.25\end{array}$ & 0.4502 \\
\hline $\begin{array}{l}\text { Total non-edible } \\
\text { parts }(\%)\end{array}$ & $\begin{array}{l}30.37 \\
\pm 0.67\end{array}$ & $\begin{array}{l}31.45 \\
\pm 0.98\end{array}$ & $\begin{array}{l}31.97 \\
\pm 1.27\end{array}$ & $\begin{array}{l}30.38 \\
\pm 0.91\end{array}$ & $\begin{array}{l}29.37 \\
\pm 1.25\end{array}$ & 0.4502 \\
\hline
\end{tabular}

The results herein were in accordance with those found by AguilarYáñez et al. (2011) who showed insignificant differences in carcass characteristics of lambs fed diets included fresh or dehydrated spineless cactus. Besides, Abu Shammalah, (2007) demonstrated that rabbits fed diet containing prickly pear at levels of 40,60 and $80 \%$ of the diet had lower abdominal fat percentage than the control group. On the other hand, Zeedan et al. (2015) indicated that rabbits fed a diet containing $30 \%$ of prickly pear had the highest values of all carcass characteristics.

The beneficial effects of prickly pear in reducing abdominal fat in rabbit's carcass may be due to that prickly pear fiber increases fecal fat excretion by binding to dietary fat, thus reducing dietary fat available for absorption and producing a better quality of the meat (Uebelhack et al. 2014). 


\section{Blood constituents and antioxidant markers}

The effects of PPF and PPP inclusion on blood constituents and antioxidant markers are shown in Table 8. Results clarify that rabbits fed diets containing PPF or PPP at levels of 25 or $50 \%$ had significantly higher $(\mathrm{P}<0.01)$ values of TAC, GSH-Px, SOD and CAT compared to the control group. It could be also observed that rabbits fed diets containing 25 and $50 \%$ PPP were the higher $(\mathrm{P}<0.05)$ in TAC compared to the other experimental rabbit groups including the control. These results confirmed that supplementing rabbit diets with PPF and PPP resulted in a positive effect on serum blood antioxidative properties as measured by total antioxidant capacity (TAC) as an indexe of oxidation and antioxidant enzymes such as glutathione peroxidase (GSH-Px), superoxide dismutase (SOD) and Catalase (CAT).

The additive and synergistic effects of phytochemicals in prickly pear are responsible for its antioxidants activity. The antioxidative ability of the prickly pear could neutralize reactive oxygen species (ROS) (Feugang et al., 2006). These ROS exert a multiplicity of biological effects across a wide range from physiological regulatory functions to damaging alterations strongly related with the pathogenesis of an increasing number of diseases (Osuna-Martinez et al. 2014 and Saih et al. 2017). The present study showed that prickly pear fruits and peel enhanced the antioxidative status of growing rabbits and protected against oxidative damage because of the presence of several antioxidants such as ascorbic acid, which is an important antioxidant and its content in prickly pear fruits and peel are considerably higher (2.4 and $2.8 \mathrm{mg} / 100 \mathrm{~g}$ ), vitamin E (25 and 28, $\mu \mathrm{g} / 100 \mathrm{~g}$ ), B-carotene (10 and $13 \mu \mathrm{g} / 100 \mathrm{~g}$ ) and phenolic acids (11745 and $14585 \mathrm{ppm}$ as gallic acid equivalent).

Regarding blood constituents, The results of the present study demonstrated that plasma total protein, albumin, A/G ratio and HDLcholesterol of rabbits fed diets containing PPF or PPE at each tested level $(25$ or $50 \%)$ were significantly higher $(\mathrm{P}<0.05)$ than those of the control group. On the contrary, plasma triglycerides, total cholesterol and LDLcholesterol concentrations were significantly lower $(\mathrm{P}<0.05)$ in rabbit groups fed PPF and PPP diets compared to the control group. Similar results were obtained by Zeedan et al. (2015) who stated that rabbits fed diets contained 10, 20 and 30\% cactus opuntia cladodes were lower $(\mathrm{P}<0.05)$ in cholesterol and LDL compared to the control group. In this work, all tested levels of prickly pear dietary supplementation reduced triglycerides, cholesterol and LDL, while increased HDL content. 
Table (8). Effect of dietary inclusion of prickly pear fruits and peel on antioxidant markers and blood constituents of growing rabbits at 13 weeks of age.

\begin{tabular}{|c|c|c|c|c|c|c|}
\hline \multirow[b]{2}{*}{ Items } & \multicolumn{5}{|c|}{ Experimental diets } & \multirow[b]{2}{*}{$P$ value } \\
\hline & Control & $\begin{array}{c}25 \% \\
\text { PPF }\end{array}$ & $\begin{array}{l}50 \% \\
\text { PPF }\end{array}$ & $\begin{array}{l}25 \% \\
\text { PPP }\end{array}$ & $\begin{array}{r}50 \% \\
\text { PPP }\end{array}$ & \\
\hline \multicolumn{7}{|l|}{ Antioxidant markers } \\
\hline \multirow[t]{2}{*}{$\mathrm{TAC}(\mathrm{mMol} / \mathrm{L})$} & $0.60^{\mathrm{c}}$ & $0.94^{\mathrm{b}}$ & $1.17^{\mathrm{b}}$ & $3.27^{\mathrm{a}}$ & $3.32^{\mathrm{a}}$ & 0.0001 \\
\hline & \pm 0.34 & \pm 0.03 & \pm 0.015 & \pm 0.24 & \pm 0.028 & \\
\hline \multirow[t]{2}{*}{ GSH-Px (mU/ml) } & $0.94^{\mathrm{d}}$ & $1.04^{\mathrm{c}}$ & $1.29^{c}$ & $2.74^{\mathrm{b}}$ & $2.20^{\mathrm{a}}$ & 0.0001 \\
\hline & \pm 0.007 & \pm 0.006 & \pm 0.033 & \pm 0.050 & \pm 0.019 & \\
\hline \multirow[t]{2}{*}{$\mathrm{SOD}(\mathrm{U} / \mathrm{l})$} & $24.54^{\mathrm{c}}$ & $31.88^{\mathrm{b}}$ & $44.68^{\mathrm{a}}$ & $44.64^{\mathrm{a}}$ & $48.64^{\mathrm{a}}$ & 0.0001 \\
\hline & \pm 2.94 & \pm 3.65 & \pm 1.41 & \pm 0.91 & \pm 0.27 & \\
\hline \multirow[t]{2}{*}{ CAT (U/g) } & $472.90^{\mathrm{c}}$ & $586.88^{\mathrm{b}}$ & $656.43^{\mathrm{a}}$ & $652.66^{\mathrm{ab}}$ & $656.80^{\mathrm{ab}}$ & \\
\hline & \pm 34.65 & \pm 18.43 & \pm 5.32 & \pm 2.67 & \pm 0.27 & 0.0001 \\
\hline \multicolumn{7}{|l|}{ Blood constituents } \\
\hline \multirow[t]{2}{*}{ Total Protein $(\mathrm{g} / \mathrm{dl})$} & $5.75^{\mathrm{c}}$ & $6.49^{\mathrm{b}}$ & $7.09^{\mathrm{a}}$ & $6.83^{\mathrm{ab}}$ & $6.57^{\mathrm{ab}}$ & 0.0003 \\
\hline & \pm 0.086 & \pm 0.26 & \pm 0.22 & \pm 0.10 & \pm 0.11 & \\
\hline \multirow[t]{2}{*}{ Albumin (g/dl) } & $2.33^{\mathrm{b}}$ & $3.31^{\mathrm{a}}$ & $3.50^{\mathrm{a}}$ & $3.27^{\mathrm{a}}$ & $3.42^{\mathrm{a}}$ & 0.0001 \\
\hline & \pm 0.086 & \pm 0.26 & \pm 0.058 & \pm 0.12 & \pm 0.128 & \\
\hline \multirow[t]{2}{*}{ Globulin (g/dl) } & 3.42 & 3.17 & 3.59 & 3.55 & 3.15 & 0.359 \\
\hline & \pm 0.084 & \pm 0.27 & \pm 0.22 & \pm 0.12 & \pm 0.18 & \\
\hline \multirow[t]{2}{*}{$\mathrm{A} / \mathrm{G}$ ratio } & $0.68^{\mathrm{b}}$ & $1.04^{\mathrm{a}}$ & $0.97^{\mathrm{a}}$ & $0.92^{\mathrm{a}}$ & $1.09^{\mathrm{a}}$ & 0.030 \\
\hline & \pm 0.035 & \pm 0.15 & \pm 0.06 & \pm 0.05 & \pm 0.10 & \\
\hline \multirow[t]{2}{*}{ Triglycerides (mg/dl) } & $69.50^{\mathrm{a}}$ & $44.23^{\mathrm{b}}$ & $42.90^{\mathrm{b}}$ & $41.83^{\mathrm{b}}$ & $47.84^{\mathrm{b}}$ & 0.0109 \\
\hline & \pm 2.66 & \pm 7.53 & \pm 7.48 & \pm 4.61 & \pm 3.48 & \\
\hline \multirow[t]{2}{*}{ Total cholesterol(mg/dl) } & $103.21^{\mathrm{a}}$ & $90.70^{\mathrm{b}}$ & $90.17^{\mathrm{b}}$ & $90.79^{\mathrm{b}}$ & $91.20^{\mathrm{b}}$ & 0.0001 \\
\hline & \pm 1.95 & \pm 1.76 & \pm 1.64 & \pm 1.25 & \pm 1.08 & \\
\hline \multirow[t]{2}{*}{ HDL- cholesterol (mg/dl) } & $34.10^{\mathrm{b}}$ & $43.21^{\mathrm{a}}$ & $45.84^{\mathrm{a}}$ & $46.33^{\mathrm{a}}$ & $43.98^{\mathrm{a}}$ & 0.027 \\
\hline & \pm 0.31 & \pm 2.39 & \pm 2.94 & \pm 4.30 & \pm 1.76 & \\
\hline \multirow[t]{2}{*}{ LDL - cholesterol (mg/dl) } & $41.02^{\mathrm{a}}$ & $30.85^{\mathrm{b}}$ & $34.31^{\mathrm{b}}$ & $33.73^{\mathrm{b}}$ & $34.25^{\mathrm{b}}$ & 0.0016 \\
\hline & \pm 2.11 & \pm 0.47 & \pm 1.55 & \pm 1.11 & \pm 1.55 & \\
\hline
\end{tabular}

a,b,c,d Means with different superscripts in each raw differ significantly $(\mathrm{P}<0.05)$.

PPF = Prickly pear fruit and PPP = Prickly pear peel. Superoxide dismutase (SOD), glutathione peroxidase (GSH-Px), Total antioxidant capacity (TAC) and catalase (CAT). Albumin/globulin ratio (A/G), high density lipoprotein (HDL) and low density lipoprotein (LDL).

Prickly pear contains pectin, which interferes with cholesterol and lipids synthesis, through binding cholesterol to bile acids (Louacini et al. 2012; Zeedan et al. 2015 and Nazareno, 2017) and then when the concentrations of these compounds increase, they accelerate the catabolism of cholesterol (Louacini et al. 2012). Moreover, the interaction among flavonoids, betalaines and vitamin $\mathrm{E}$ seems to be responsible for the hypolipidemic activity of prickly pear (Lee and Lim, 2000). 


\section{Economical efficiency}

As shown in Table 9. The inclusion of PPF or PPP in rabbit diets at $25,50 \%$ showed an improvement in both economical efficiency and net revenue compared to the control group. This beneficial effect could be attributed to the reduction of total feed cost because prickly pear fruit and peel are so competitive in price as compared to other energy feed sources used in rabbits feeding like as barley. Additionally, rabbits fed 50\% PPP recorded the best net revenue. This is improvement matched with that reported by Zeedan et al. (2015) who stated that inclusion of cactus opuntia cladodes at 10, 20 and 30\% levels in growing rabbits diets improved the total revenue and economical efficiency.

Prickly pear fruits and peel will be available as alternative energy sources for rabbit nutrition especially when corn and barley are expensive or unavailable. Due to concerns about global desertification and declining water sources, Opuntia spp. are gaining in importance as an effective energy source of feed.

Table (9). Economic efficiency of the experimental diets containing prickly pear fruits and peels.

\begin{tabular}{|c|c|c|c|c|c|}
\hline \multirow[b]{2}{*}{ Item } & \multicolumn{5}{|c|}{ Experimental diets } \\
\hline & Control & $\begin{array}{l}25 \% \\
\text { PPF }\end{array}$ & $\begin{array}{l}50 \% \\
\text { PPF }\end{array}$ & $\begin{array}{l}25 \% \\
\text { PPP }\end{array}$ & $\begin{array}{l}50 \% \\
\text { PPP }\end{array}$ \\
\hline Initial weight $(\mathrm{Kg})$ & 0.608 & 0.576 & 0.608 & 0.581 & 0.606 \\
\hline Final weight $(\mathrm{Kg})$ & 1.796 & 1.715 & 1.811 & 1.735 & 1.839 \\
\hline Average total weight gain/rabbit (kg) & 1.188 & 1.139 & 1.203 & 1.154 & 1.233 \\
\hline Total revenue /rabbit (LE) ${ }^{1}$ & 41.58 & 39.865 & $\begin{array}{c}42.10 \\
5\end{array}$ & 40.39 & 43.155 \\
\hline Total feed intake/rabbit $(\mathrm{Kg})^{2}$ & 3.232 & 3.087 & 3.135 & 3.096 & 3.244 \\
\hline Price of feeding $/ \mathrm{kg}(\mathrm{LE})$ & 3.85 & 3.25 & 3.15 & 3.2 & 3.1 \\
\hline Total feed cost /rabbit (LE) & 12.44 & 10.03 & 9.88 & 9.91 & 10.06 \\
\hline Net revenue/rabbit $(\mathrm{LE})^{3}$ & 29.14 & 29.83 & 32.23 & 30.48 & 33.10 \\
\hline Economic efficiency $(E E)^{4}$ & 2.34 & 2.97 & 3.26 & 3.08 & 3.29 \\
\hline Relative economic efficiency (REE) ${ }^{5}$ & 100.00 & 127.00 & 139.40 & 131.42 & 140.58 \\
\hline
\end{tabular}

${ }^{I}$ Assuming that the price of one $\mathrm{kg} L B W$ equal, 35 L.E.

${ }^{2}$ According to the price of ingredients available at the experimental time.

${ }^{3}$ Net revenue/rabbit $=$ Total revenue / rabbit $(L E)$ - Total feed cost / rabbit (LE)

${ }^{4} E E=$ Net revenue / Total feed cost / rabbit $(L E)$.

${ }^{5} R E E=E E$ of treatments other than the control/ EE of the control group.

In conclusion, the inclusion of the prickly pear fruits and peel in the rabbit diets at 25 and $50 \%$ as a replacement of barley had positive effects on 
the performance of rabbits and moreover, prickly pear fruits and peel are the excellent sources of dietary antioxidants components which may have beneficial effects on rabbit's health, being rich in bioactive antioxidant compounds (vitamin A, E, ascorbic acid and polyphenols) which make it a worth and viable feeding strategy. From the economical point of view especially within a sustainable animal production system, prickly pear could be promising energy feedstuff.

\section{REFERENCES}

Abdel-Nabey, A.A. (2001). Chemical and technological studies on cactus pear (Opuntia ficus-indica) fruits. Alex J Agric Res, 46: 61-70.

Abu Shammalah, K.N. (2007). Evaluation of cactus (Opuntia Sp.) as forage source for growing rabbits in the Gaza Strip. M.Sc. Thesis, Faculty of Science, the Islamic University, Gaza.

Aebi H. (1984). Catalase in vitro. Methods Enzymol., 105:121-126.

Aguilar-Yáñez, M.I.; Hernández-Mendo, O.; Guerrero-Legarreta, I.; RamírezBribiesca, J.E.; Aranda-Osorio, G. and Crosby-Galvan, M.M. (2011). Productive response of lambs fed with fresh or dehydrated spineless cactus (Opuntia ficus-indica L.). J. Professional Association for Cactus Development, 13: 23-35.

Amogne, F.T. (2007). Evaluation of alternative feed resources for ruminants under arid zones of the tropics and sub-tropics: The case of cactus pear (Opuntia ficus-indica) in Ethiopia. Ph.D. Thesis, Humboldt-Universität zu Berlin, Germany.

AOAC. (2005). Official Methods of Analysis. Association of Official Analytical chemists. $18^{\text {th }}$ ed. Washington, DC, USA.

Atef, A.M.; Abou-Zaid, N.; Ibrahim, I.; Mostafa, T.R. and Nadir, A. (2013). Quality evaluation of sheets, jam and juice from prickly pear and melon blends. Life Sci. J., 10: 200-208.

Aware, M.J.; Ghavate, A.M.; Pundo, K.K. and Kauthale, V.K. (2017). Influence of feeding spineless cactus on growth performance of Osmanabadi goat kids. In Proc.: The IX International Congress on Cactus Pear and Cochineal "CAM crops for a hotter and dried world", 26-30 March, Coquimbo, Chile, (Abstract).

Belenguar, A.; Fondevila, M.; Balcells, J. and Torre, C. (2000). Effect of the source and level of cereal in diet on the rabbit caecal environment and microbial population. Proceedings of the $7^{\text {th }}$ World Rabbit Congress, July 5-7, WRSA, University of Valence, Valence, Spain, pp: 95-100. 
Ben Salem, H.; Nefzaoui, A.; Abdouli, H. and Ørskov, E.R. (1996). Effect of increasing level of spineless cactus (Opuntia ficus-indica var. Inermis) on intake and digestion by sheep given straw-based diets. Anim. Sci., 62: 293-299.

Bhatt, M.R. and Nagar, P.S. (2013). Evaluation of physicochemical property and fatty acid composition of Opuntia elatior seed oil. J. Professional Association for Cactus Development, 15: 13-19.

Blasco, A. and Ouhayoun, J. (1996). Harmonization of criteria and terminology in rabbit meat research. World Rabbit Sci., 4, 93-99.

Bouzoubaâ, Z.; Essoukrati, Y.; Tahrouch, S.; Hatimi, A.; Gharby, S. and Harhar, H. (2016). Phytochemical study of prickly pear from Southern Morocco. J. Saudi Society Agric. Sci., 15: 155-161.

Burn, R.E. (1971). Method of estimation of tannin in the grain sorghum. Agronomy J., 163: 511-519.

Carabaño R.; Villamide M.J.; García J.; Nicodemus N.; Llorente A.; Chamorro S.; Menoyo, D.; García-Rebollar, P.; García-Ruiz, A.I. and De Blas J.C. (2009). New concepts and objectives for protein amino acid nutrition in rabbits. World Rabbit Sci., 17: 1-14.

Cardosoa, D.B.; de Carvalhoa, F.F. R.; de Medeirosb, G. R.; Guima, A.; Cabralc, A. M. D.; Verasd, R. M. L.; dos Santosa, K. C.; Dantasb, L. C. N. and Nascimento, A. G. D.(2019). Levels of inclusion of spineless cactus (Nopalea cochenillifera Salm Dyck) in the diet of lambs. Anim. Feed Sci. and Technol., 247 (2019) 23-31.

Cheeke, P.R.; Patton, N.M. and Tempelton, G.S. (1982). Rabbit Production. 5th Edition, Interstate printers and publishers, Inc. Danville II., USA.

Chiu, D.T.Y.; Stults, F.H. and Tappel, A.L. (1976). Purification and properties of rat lung soluble glu- tathione peroxidase. Biochim. Biophys. Acta, 445:558-566.

Conway, E.J. (1958). Micro-Diffusion Analysis And Volumetric Error, $4^{\text {th }}$ ed. The McMillan Co., NY, USA.

Cordova-Torres, A.V.; Costa, R.G.; Guerra, R.R.; Araújo Filho, J.T.; Medeiros, A.N. and Rocha, E.H.S. (2017). Morphometry of rumen and intestinal tissues of sheep with dietary levels of forage cactus and water restriction. In Proc.: The IX International Congress on Cactus Pear and Cochineal "CAM crops for a hotter and dried world", 26-30 March, Coquimbo, Chile (Abstract).

Danish Official (1996). Vitamin C Determination. Method No. 113.2. Authorized by National Food Agency of Denmark. 
De Oliveira, J. P. F.; De Andrade Ferreira, M.; Alves, A. M. S. V.; De Melo, A. C. C.; De Andrade, I. B.; Suassuna, J. M. A. and De Lima S., J. (2017). Spineless cactus as a replacement for sugarcane in the diets of finishing lambs. Trop. Anim. Health and Prod., 49(1): 139-144.

Doumas, B.T.; Watson, W.A. and Biggs, H.G. (1971). Albumin standards and the measurement of serum albumin with bromcresol green. Clin Chem Acta., 31:87-96.

Duncan, D.B. (1955). Multiple Range and Multiple F-Test. Biometrics, 11:142. ed. 32, 57-58.

EL-Mostafa, K.; EL Kharrassi, Y.; Badreddine, A.; Andreoletti, P.; Vamecq, J.; EL Kebbaj, M.S.; Latruffe, N.; Lizard, G.; Nasser, B. and CherkaouiMalki, M. (2014). Nopal Cactus (Opuntia ficus-indica) as a Source of Bioactive Compounds for Nutrition, Health and Disease. Molecules, 19: 14879-14901.

Ennouri, M.; Ammar, I.; Khemakhem, B. and Attia, H. (2014). Chemical composition and antibacterial activity of Opuntia Ficus-Indica F. Inermis (Cactus Pear) flowers. J Med Food, 17: 908-914.

FAO (2014). Electronic database of the Food and Agriculture Organization. Available at: http://www.fao.org/faostat/en/\#data/QCFAOSTAT.

Fernández-López, J.A.; Almela, L.; Obón, J.M. and Castellar, R. (2010). Determination of antioxidant constituents in Cactus Pear fruits. Plant Food Hum. Nutr., 65: 253-259.

Feugang, J.M.; Konarski, P.; Zou, D.; Stintzing, F.C. and Zou, C. (2006). Nutritional and medicinal use of Cactus pear (Opuntia spp.) cladodes and fruits. Front Biosci, 11: 2574-2589.

Fortun-Lamothe, L. and Boullier, S. (2007). A review on the interactions between gut microflora and digestive mucosal immunity. Possible ways to improve the health of rabbits. Livest. Sci., 107: 1-18.

Gabriel, A.; Victor, N. and James Du Preez, C. (2014). Cactus pear biomass, a potential lignocellulose raw material for Single Cell Protein production (SCP): A Review. Int. J. Curr. Microbiol. App. Sci., 3: 171-197.

Gengatharan, A.; Dykes, G.A. and Choo, W.S. (2015). Betalains: Natural plant pigments with potential application in functional foods. LWT-Food Sci. Technol., 64: 645-649.

Guevara-Figueroa, T.; Nez-Islas, H.J.; Reyes-Escogido, M.L.; Mortensen, A.G.; Bente, B.; Laursen, B.B.; Lin, L.; De Leo'n-Rodri'guez, A.; Fomsgaard, I.S. and De La Rosa, A.B. (2010). Proximate composition, phenolic acids, and flavonoids characterization of commercial and wild nopal (Opuntia spp.). J. Food Compos. Anal., 23: 525-532. 
Islam, M.; Razzaq, A.; Sawsan, H.; Louhaichi, M.; Qamar, I.A.; Rischkowsky, B.A. and Ibrahim, M.N.M. (2017). Assessment of different supplemental feeding strategies including cactus (Opuntia ficus-indica) for high sheep productivity in Chakwal, Pakistan. In Proc.: The IX International Congress on Cactus Pear and Cochineal "CAM crops for a hotter and dried world", 26-30 March, Coquimbo, Chile (Abstract).

Koracevic, D.; Koracevic, G.; Djordjevic, V.; Andrejevic, S. and Cosic, V. (2001). Method for the measurement of antioxidant activity in human fluids. J. Clin. Pathol., 54:356-361.

Lebas, F. (2013). Feeding strategy for small and medium scale rabbit. In Proc.: The $3^{\text {rd }}$ Conference of Asian Rabbit Production Association, 27-29 August, Bali Indonesia, Pp: 1-15.

Lebas, F.; Coudert, P.; Rouvier, R. and Rochambeau, H. (1986). The Rabbit; Husbandry, Health and Production. FAO Animal Production and Health Series, No 21.

Lee, J.C. and Lim, K.T. (2000). Effects of cactus and ginger extracts as dietary antioxidants on reactive oxidant and plasma lipid level. Food Sci. Biotechnol., 9: 83-88.

Leth, T. and Jacobsen, J.S. (1993). Vitamin A in Danish pig, calf and ox live. J. food Comps. Anal., 6: 3-9.

Leth, T. and Sondergaro, H. (1983). Biological activity of all trance-tocopherol determined by three different rat bioassays. Int. J. Vitam. Nutr. Res., 53: 297-311.

López-Garcia, J.J.; Fuentes-Rodriguez, J.M. and Rodriguez, R.A. (2001). Production and use of Opuntia as forage in Northern Mexico. In: Cactus (Opuntia spp.) as forage. Edited by Mondragón-Jacobo, C. and PerezGonzáléz, S., FAO Plant Production and Protection paper, 169. Pp.146.

Lopez-Virella, M.F.; Stone, P.; Ellis, S. and Colwell, JA. (1977). Cholesterol determination in high-density lipoproteins separated by three different methods. Clin. Chem. 23:882-884.

Louacini, B.K.; Dellal, A., Hallbouche, M. and Ghazi, K. (2012). Effect of incorporation of the spineless Opuntia ficus Indica in diets on biochemical parameters and its impact on the average weight of ewes during the maintenance. Glob. Vet., 8: 352-359.

Makkar, H.P.S. (2017). Cactus as a fodder and beyond. Broadening Horizons. Available at: $w w w$.feedipedia.org (accessed 25 April 2017).

Marty, J. and Vernay, M. (1984). Adsorption and metabolism of the volatile fatty acids in the hindgut of the rabbit. Br. J. Nutr., 51:265-277. 
Misra, A.K.; Mishra, A.S., Tripathi, M.K., Chaturvedi, O.H.; Vaithiyanathan, S.; Prasad, R. and Jakhmola, R.C. (2006). Intake, digestion and microbial protein synthesis in sheep on hay supplemented with prickly pear cactus [Opuntia ficus-indica (L.) Mill.] with or without groundnut meal. Small Ruminant Res., 63: 125-134.

Misra, H.P. and Fridovich, I. (1972). The role of superoxide anion in the autoxidation of epinephrine and a simple assay for superoxide dismutase. J. Biol. Chem. 247:3170-3175.

Nazareno, M. (2017). Recent advances in medicinal and nutraceutical properties of cactus products. In Proc.: The IX International Congress on Cactus Pear and Cochineal "CAM crops for a hotter and dried world", 26-30 March, Coquimbo, Chile (Abstract).

Nefzaoui, A. (2017). Cacti as an adaptation option for livestock feeding under changing climate in the dry areas. In Proc.: The IX International Congress on Cactus Pear and Cochineal "CAM crops for a hotter and dried world", 26-30 March, Coquimbo, Chile (Abstract).

Nefzaoui, A. and Ben Salem, H. (2001). Opuntia -a strategic fodder and efficient tool to combat desertification in the WANA region. In: Mondragón, C., Pérez, S. (Eds), Cactus (Opuntia spp.) as forage, Vol. 169. FAO Plant Production and Protection Paper, pp. 73-90.

Nobel, P.S. and Bobich, E.G. (2002). Environmental biology. In P.S. Nobel, ed. Cacti, biology and uses. ed. University of California Press, Los Angeles, California, United States of America, pp. 57-74.

Orsonneau, J.L.; Douet, P.; Massoube, C.; Lustenberger, P. and Bernard, S. (1989). An improved pyrogallol red-molybdate method for determining total urinary protein. Clin. Chem.; 35: 2233-2236.

Osuna-Martinez, U.; Reyes-Esparza, J. and Rodríguez-Fragoso, L. (2014). Cactus (Opuntia ficus-indica): A review on its antioxidants properties and potential pharmacological use in chronic diseases. Natural Products Chem. Res., 2: 153.

Perez, J.M.; Lebas, F.; Gidenne, T.; Maertens, L.; Xiccato, G.; Parigi-Bini, R.; Dalle Zotte, A.; Cossu, M.E.; Carazzolo, A.; Villamide, M.J.; Carabaño, R.; Fraga, M.J.; Ramos, M.A.; Cervera, C.; Blas, E.; Fernandez, J.; Falcao, E.; Cunha, L. and Bengala Freire, J. (1995). European reference method for IN VIVO determination of diet digestibility in rabbits. World Rabbit Sci., 3: 41-43.

Piattoni, F.; Maertens, L. and Demeyer, D. (1995). Age dependent variation of caecal composition of young rabbits. Arch. Anim. Nutr. 48:347-355. 
Prohászka, D.L. and Szemerédi, G. (1984). Regulation of the metabolism of volatile fatty acids in the caecum of rabbits. Zoonoses and Public health, 31: 358-366.

Ragab, M.S. (2007). Replacing yellow corn with prickly pear peels in growing Japanese quail diets with or without enzyme supplementation. Fayoum J. Agric. Res. \& Dev., 21: 97-112.

Ramadan, M.F. and Mörsel, J. (2010). Recovered lipids from prickly pear [Opuntia ficus-indica (L.) Mill] peel: a good source of polyunsaturated fatty acids, natural antioxidant vitamins and sterols. Food Chem., 83: 447456.

Rodriguez-Garcia, M.E.; De Lira, C.; Hernández-Becerra, E.; CornejoVillegad, M.A.; Palacios-Fonseca, A.J.; Rojas- Molina, I.; Reynoso, R.; Quintero, L.C.; Del Real, A.; Zepeda, A. and Muňoz-Torres, C. (2007). Physicochemical characterization of Nopal pads (Opuntia ficus indica) and dry vacuum nopal powder as a function of the maturation. Plant Food Hum. Nutr., 62: 107-112.

Sahoo, A.; Chaturved, O.H.; Thirumurugan, P. and Naqvi, S.M.K. (2017). Cactus: ensuring round the year feed supply. National Innovation in Climate Resilient Agriculture, Central Sheep and wool Research Institute. Avikanagar. Pp.32.

Saih, F.; Andreoletti, P.; Mandard, S.; Latruffe, N.; EL Kebbaj, M.S.; Lizard, G.; Nasser, B. and Cherkaout-Malki, M. (2017). Protective effect of cactus cladode extracts on peroxisomal functions in microglial $\mathrm{BV}-2$ cells activated by different lipopolysaccharides. Molecules, 22: 102.

Salim, N.; Abdelwaheb, C.; Rabah, C. and Ahcene, B. (2009). Chemical composition of Opuntia ficus-indica (L.) fruit. African Journal of Biotechnology, 8 (8): 1623-1624.

SAS. 2009. SAS User's Guide. Statistics. Version 9.1, SAS Institute Inc., Cary, NC, USA.

Schneider, B.H. and Flatt, W.P. (1975). The evaluation of feed through digestibility experiments. University of Georgia Experiments .University of Georgia Press Athens, Georgia, USA.423 pp.

Shahidi, F.; Janitha, P.K. and Wanasundara, P.D. (1992). Phenolic antioxidant, Critcal previous term reviews next term. Crit. Rev. Food Sci. Nutr., 32: 67-103.

Shany, S.; Yehudith, B.; Gestetner, B. and Bondi, A. (1970). Properties, characterization and some properties of saponins from Lucerne tops and roots. J. Sci. Food Agric., 21: 131-135. 
Steven, W.D.; Hohenboken, W.D.; Cheeke, P.R.; Patton, N.M. and Kennick, W.H. (1981). Carcass and meat characteristics of Flemish giant and New Zealand white purebred and terminal cross rabbits. J. of Applied Rabbit Res., 4 (3), 66-72.

Sumaya-Martínez, M.T.; Cruz-Jaime, S.; Madrigal-Santillán, E.; GarcíaParedes, J.D.; Cariño-Cortés, R.; Cruz-Cansino, N.; Valadez-Vega, C.; Martinez-Cardenas, L. and Alanís-García, E. (2011). Betalain, acid ascorbic, phenolic contents and antioxidant properties of purple, red, yellow and white cactus pears. Int. J. Mol. Sci., 12: 6452-6468.

Uebelhack, R. M. P.; Busch, R.; Alt,F.; Beah, Z.M. and Chong, P.W. (2014). Effects of cactus fiber on the excretion of dietary fat in healthy subjects: a double blind, randomized, placebo-controlled, crossover clinical investigation. Curr. Ther. Res., 76: 39-44.

Van Soest, P.J.; Robertson, J.B. and Lewis, B.A. (1991). Methods for dietary fiber, neutral detergent fiber and non-starch polysaccharides in relation to animal nutrition. J. Dairy Sci., 74: 3583-3597.

Wahlefeld, A.W. (1974). Triglycerides determination after enzymatic hydrolysis. In: Bergmeyer HU, editor. Methods Of Enzymatic Analysis. New York (NY): Academic Press; p. 1831-1835.

Warner, A.C.I. (1964). Production of volatile fatty acid in the rumen. 1: Method of measurements. Nutr. Abst. Rev., 34: 339-410.

Yahia, E.M. and Mondragon-Jacobo, C. (2011). Nutritional components and anti-oxidant capacity of ten cultivars and lines of cactus pear fruit (Opuntia spp.). Food Res. Int., 44: 2311-2318.

Zeedan, KH.I.; EL-Neney, B.A.; Abd EL-Latif, A.I.; Awadien, N.B. and Ebeid, T.A. (2015). Effect of using residues prickly pear as a source of dietary feedstuffs on productive performance, biological traits and immune response of rabbit. 1- Prickly pear cladodes. Egypt Poultry Sci. J., 35: 923-943.

Zeeman, D.Z. (2005). Evaluation of sun-dried Opuntia ficus-indica var. Algerian cladodes in sheep diets. M.Sc. Thesis, University of the Free State, Bloemfontein, South Africa.

Zenteno-Ramírez, G.; Juárez-Flores, B.I.; Aguirre-Rivera, J.R.; MonrealMontes, M.; Mérida García, J.; Pérez Serratosa, M.;Varo Santos, M.Á.; Ortiz Pérez, M.D. and Rendón-Huerta, J.A. (2018). Juices of prickly pear fruits (Opuntia Spp.) as functional foods. Ital. J. Food Sci., 30: 614-627. 
تأثير استخدام التين الثوكي ومخلفاته كمصادر علفية بديلة علي أداء الأرانب النامية.

افوزيه عامر حسان، بامسيه مصطفي مبارز، بمحمد محمد بسيوني، بخالد

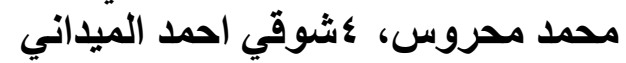

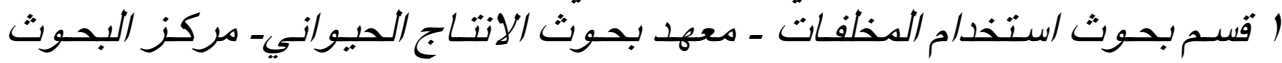
الزراعية- الدقي- الجبزة- مصر.

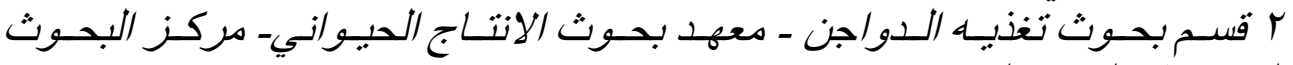

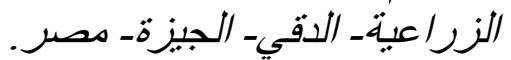

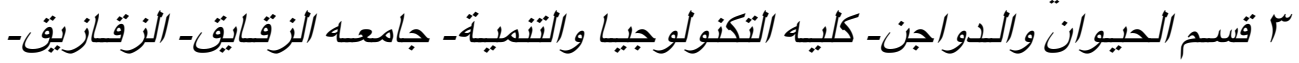

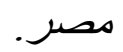
عالدركز الاقليم للاغذيه والاعلاف - مركز البحوث الزر/عيه_الجيزه-مصر.

استهدفت الدر اسة الحالية تقييم تأثنير إحلال مستويات مختلفه من ثمار وقثتر التين

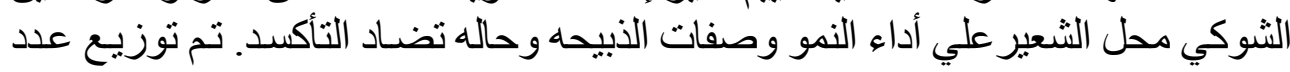

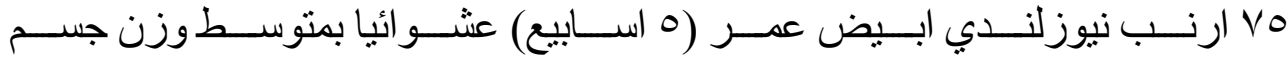

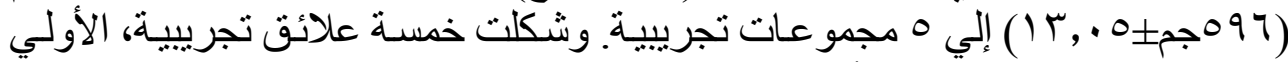
استخدمت كعليقه كنترول، و الأربعة علائق الاخري تم استبدال الثعير بثــار وفثنر التين

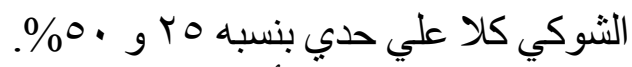

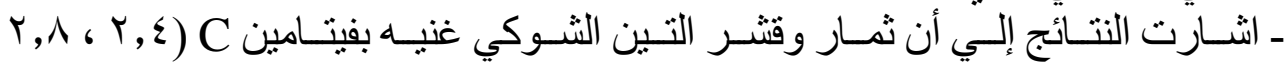

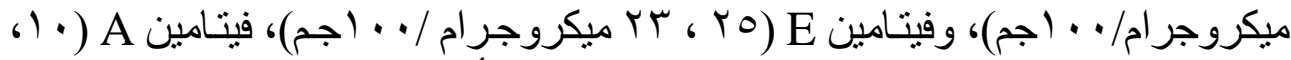

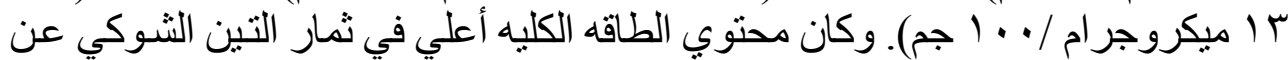

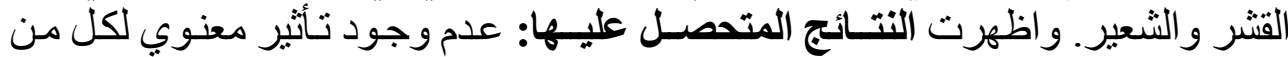

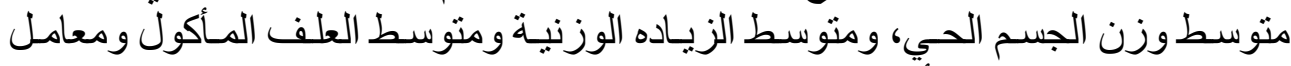

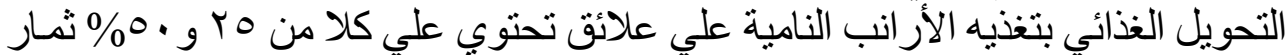

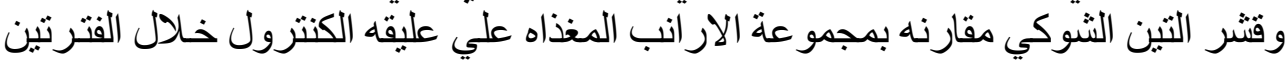

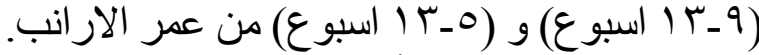

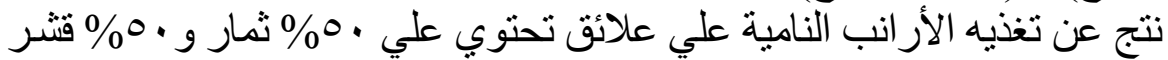

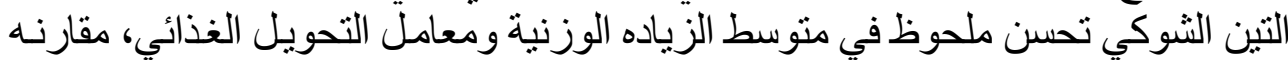

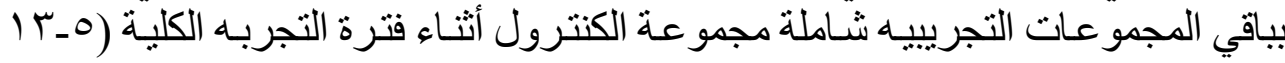

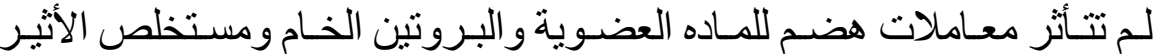

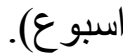

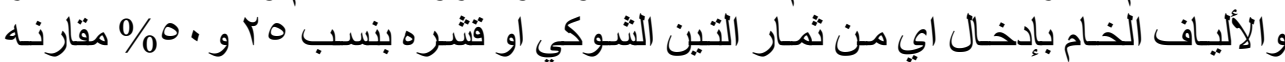
بمجمو عه الكنترول. ولم يكن هنالك ايضا فروق غير التير معنويـه في المركبـات الغذائيه الكليه 


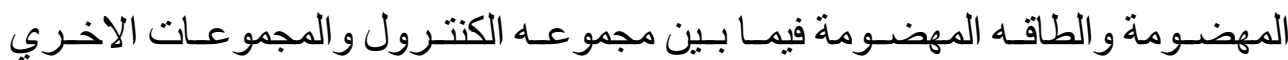

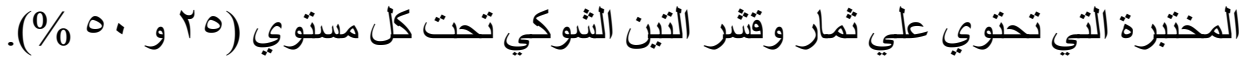

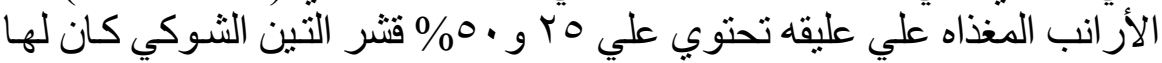

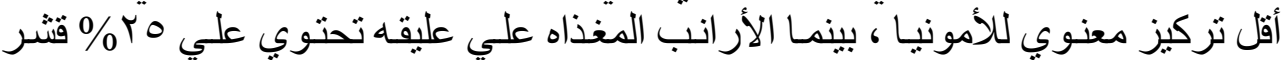

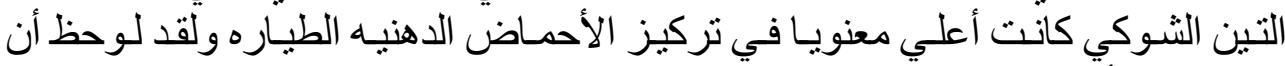

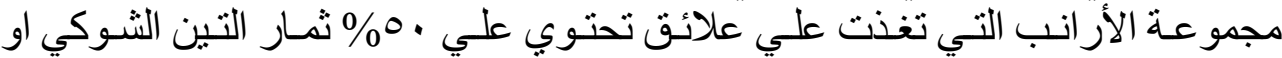

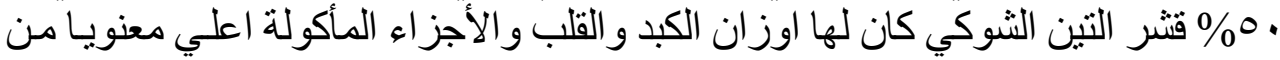

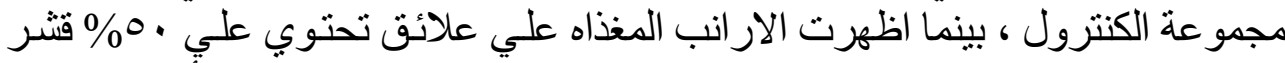

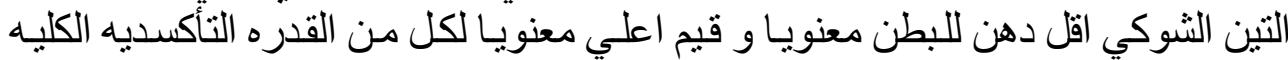

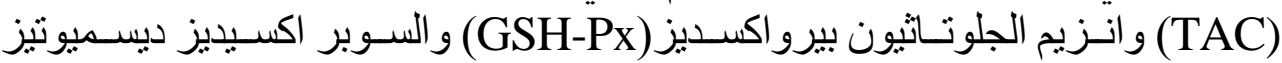

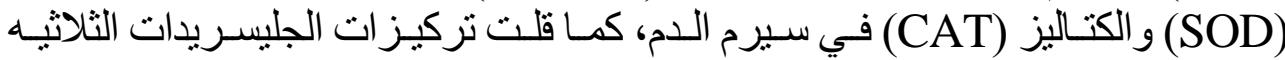

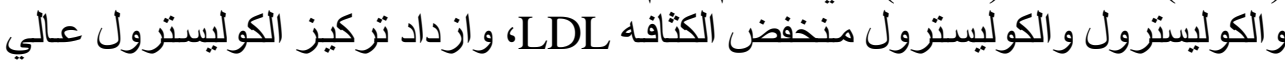

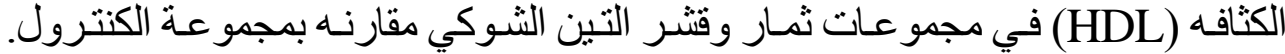

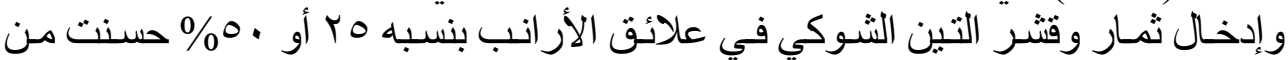

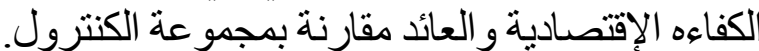

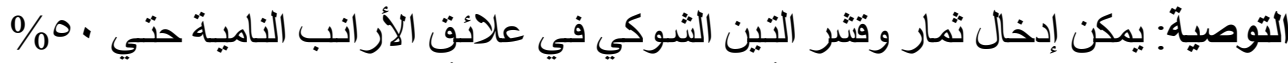

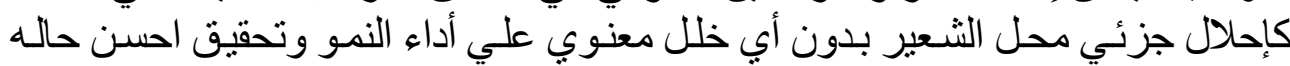
مضاده للتأكسد للأر انب و اعلي كفاءه إقتصاديه للعلائق. 